\title{
Audience Commodification: A Source of Innovation in Business Models
} Datis Khajeheian

\author{
"If you create incredible value and information for others..." \\ and you always stay focused on that service, the financial \\ success will follow.
}

\author{
Brendon Burchard \\ Author and motivational speaker
}

\begin{abstract}
This article reports on a research project aimed at developing a business model by changing the value-creation mechanism. The essence of this change is to persuade customers to perform actions in favour of the service provider. Such actions include responding to advertising clips to unlock value. The business model was generated from the concept of audience commodification and is based on the idea of looking at users as a source of a tradeable asset in business-to-business markets. Here, attention and actions are the assets that users pay to access the proposed value. The research includes two phases of surveys and experimentation. In the first phase, the tendency and acceptance level of users towards watching advertisements to unlock value are measured. In the next phase, a platform prototype is developed to test and understand user actions towards receiving value. The sample includes 52 users of different nationalities who were seeking relationships on an online dating platform. Results revealed that users accept advertising and will perform requested actions if they can perceive the delivered value. Practical implications of this research include insights to help move away from the current "view-based" advertising model toward new models of partnership with users in the value-creation process. This research may also stimulate further research into developing sustainable business models based on advertising revenue.
\end{abstract}

\section{Introduction}

Information as the basic product of media is increasingly available for users, easily and mostly free (James, 2012). The volume of media products and services now offered by many media service providers has changed the base of economics in the media industry from being based on scarcity to being based on abundance (Darr \& Jürgen, 2008; Masiello \& Whitten, 2010). Owing to this change, audience attention becomes a scarce commodity and not an information and media product (Falkinger, 2008). This trend produces a challenge for media companies and enterprises to reach their target, and it requires them to search for new business models to deliver value and generate profit (Chesbrough, 2007; Johnson et al., 2008; Morris et al., 2005).

There is a shift toward content being free, and business models based on subscription and pay-per-view are ex- periencing difficulties attracting customers. One example of this competition can be seen in the business of online dating. The proliferation of dating sites compels companies to seek new market segments and try to attract new niche audiences. Most such platforms mainly follow the subscription-based model as the major business model for premium dating services. While time, attention, and energy are the resources that every advertiser seeks, users of dating services spend a lot of time and efforts to find and connect to potential partners. The abundance of those resources in dating platforms as well as the emotional nature of their proposed value have given this industry potential for generating money from other business models. Thus, this industry was chosen as the focus of a research project facilitated to develop a dynamic business model through valuesystem innovation. The author, who is an entrepreneur and scholar, managed this research to develop a workable business model for a dating platform. In the face of 


\section{Audience Commodification: A Source of Innovation in Business Models}

\section{Datis Khajeheian}

tough competition and increasing difficulties in attracting users in the online dating industry, this research phase asks:

\section{"How can a dynamic business model be formed based on direct trade-offs of the attention and value between customers and businesses?"}

This article is structured as follows. First, the literature on audience commodification and business models are briefly reviewed. Next, the methodology is described, including the construction of a prototype social dating platform to test the behaviour of users and their acceptance of the business model. Then, the results are analyzed and the practical implications of the findings are discussed. Finally, conclusions are provided.

\section{Literature Review}

\section{Audience commodification}

The concept of audience commodity originates from the political economy of communication. It was a political issue discussed by Smythe (1977) to show that western Marxist analyses have neglected the economic and political significance of mass communications. Some authors, from the field of political economy of communication, have stressed the processes of accumulation as the creator of commodification that forced humans to sell their labour power for wages (Murdock, 2011; Prodnik, 2012). Many authors in the field study commodification with a critical perspective (Fuchs, 2012; Smythe, 1981; Suddaby \& Greenwood, 2001).

Smythe applied Marx's idea of media as a means of communication. In referring to advertisers, he suggested that, "What they buy are the services of audiences with predictable specifications who will pay attention in predictable numbers and at particular times to particular means of communication. As collectivities, these audiences are commodities. As commodities, they are dealt with in markets by producers and buyers (advertisers)" (Smythe, 1977). In essence, his theory suggested that media industries are based on the transformation of audiences into commodities that can be sold on to advertisers (Arvidsson \& Bonini, 2015).

The concept expands to studies on business models based on how Google considers users as a commodity for advertising. Kang and McAllister (2011) argue that Google generates value from advertising by its extensive and transformative commodification of users and its unique features as an advertising venue, intensifying the commodification of its users as compared to tradi- tional media. In contradiction with many critics of audience commodification in the political economy of communication, the success of Google in generating revenues introduced us to an innovation in business development (Osterwalder \& Pigneur, 2010).

Many researchers argue that commodification can be used as a tool for value generation (e.g., DiZerega, 2004; Fleissner, 2006; Thorén, 2011). They argue that new technologies increase the power of media giants and businesses to commodify audiences and to sell them to advertisers. Among these researchers, Manzerolle (2010) proposes the phrase "prosumer commodification" to explain participation of users in this process, too. Hearn (2008) has a critical perspective and debates about self-commodification under variety of digital labour practices. In any case, by using new technologies, users perform actions that make themselves easier to commodify by businesses. Some researchers such as Jennes (2014) oppose the negative sense of audience commodification by introducing "audience empowerment" and argue that digital technology can also enable users in dealing with the surrounding environment.

\section{Business models}

According to Morris, Schindehutte, and Allen (2005), there is no generally accepted definition for the term "business model". The diversity in definitions "poses substantive challenges for delimiting the nature and components of a model and determining what constitutes a good model. It also leads to confusion in terminology, as business model, strategy, business concept, revenue model, and economic model are often used interchangeably. Moreover, the business model has been referred to as an architecture, design, pattern, plan, method, assumption, and statement" (Morris et al., 2005). A simple definition of business model comes from Stewart and Zhao (2000), who define it as a statement of how a firm will make money and sustain its profit stream over time. According to Osterwalder and Pigneur (2010), a business model describes the rationale of how an organization creates, delivers, and captures value. In a more detailed explanation, Chesbrough (2010) defines a business model by the following characteristics: "It articulates the value proposition; identifies a market segment and specify the revenue generation mechanism; defines the structure of the value chain required to create and distribute the offering and complementary assets needed to support position in the chain; details the revenue mechanism(s) by which the firm will be paid for the offering; estimates the cost structure and profit potential (given value proposition and value chain structure); describes the posi- 


\section{Audience Commodification: A Source of Innovation in Business Models}

\section{Datis Khajeheian}

tion of the firm within the value network linking suppliers and customers (including identifying potential complementors and competitors); and formulates the competitive strategy by which the innovating firm will gain and hold advantage over rivals." Although different researchers argue that there is limited attention to a definition of business model (Chesbrough, 2007; Falkinger, 2008; Zott \& Amit, 2008), the different definitions agree on an important point: a business can create value and earn income.

All in all, the business model holds promise as a unifying unit of analysis that can facilitate theory development in entrepreneurship (Morris et al., 2005) and businesses (Chesbrough, 2007). Technology by itself has no single objective value and the economic value of a technology remains latent until it is commercialized in some way via a business model (Chesbrough, 2007). Even strategy making and strategy implementation, which are very important factors in success of companies (De Mare et al., 2015; Radomska, 2015) depend on the business model of a company, which determines the strategy to follow.

Business model innovation allows companies to develop and innovate to stay competitive. Through better understanding of how customers might be used or involved in business model innovation, there is much to gain for companies wanting to innovate their business model (Ekdahl \& Sandell, 2014). Various types of business models have been introduced and applied by different companies and businesses. A dynamic business model is a contingency-based issue, and every enterprise should select a business model that suits its characteristics. No one universal model of sustainability can be applied successfully to different types of organizations: the right choice is closely related to nature of the company's strategy (Radomska, 2015). However, in the era of rapid advances in technology and change in competitive advantages, sustainability is an important subject in the design, selection, and implementation of a business model. There are efforts in identifying sustainable business models (Hawrysz and Joachim, 2015; Radomska, 2015). Finding a sustainable business model requires consideration of different factors, including customers behaviour. Any behaviour is contingent on a perceptual filter that influences a customer's behaviour as well as other resources (Falkinger, 2008). A sustainable and durable business model should be based on this perception from value (Chesbrough \& Rosenbloom, 2002; Dubosson-Torbay et al., 2002; Hedman \& Kalling, 2003; Osterwalder, 2004; Rappa, 2004; Week, 2000; Zott et al, 2011).

\section{Methodology}

For this study, the author built a real prototype of a social dating platform to test the behaviour of users and to understand how they accept persuasion derived from the business model. The main function of this platform was for the users unlock profiles by performing actions requested by the platform. For example, suppose that a user (or "dater") wants to contact another user through their profile to start a conversation. In typical dating websites or applications, they must pay a subscription, but in this platform, subscription has been replaced with actions that directly or indirectly generate income for the company that is behind the product. For example, a user can receive points by performing certain actions, such as watching an advertising clip of 30 seconds, and they can then use these points to unlock a target profile. This mechanism replaces the subscription revenues with advertising incomes. Moreover, this solution enables media (the dating platform in this case) to provide more effective tools for advertisers. For instance, in this platform, if users answer questions at the end of an advertising clip, they gain extra points. Correct answers to questions that are related to the brand name and product features, confirm to advertisers that the clip has been seen and the audience has gained knowledge about the product.

Magretta (2002) proposed that a business model must pass two critical tests: the narrative test and the numbers test. From her perspective, a narrative test passes successfully when the story makes sense and the numbers test passes successfully when the expected profit and loss statement adds up. The researcher tested the narrative by discussing this business model in an internal seminar with some university-based experts. The experts confirmed that the mechanism and logic of this business model make sense. For the numbers test, the product has to be commercialized and is under development. The prototype and user test phase described here was used as a preliminary numbers test.

The sample includes a group of users with common characteristics of being single and having at least one account in one online dating website or mobile application. The researcher announced the test period for the developed product in three ways: by social connection with his students, friends, and connections; by inviting potential users to participate in three different workshops and seminars in which the idea was presented; and by announcing the test period on Facebook, Twitter, Google Plus, Linkedin, and his personal website. 


\section{Audience Commodification: A Source of Innovation in Business Models}

\section{Datis Khajeheian}

These sources yielded 52 volunteer testers, 14 of whom agreed to test the product in the presence of the researcher or his assistant. In the observed sessions, the researcher was able to ask questions that generated data beyond the actions that registered in the system, such as information about what might persuade users to perform certain actions, what value might encourage them to reveal personal data, etc.

The research was performed in two phases over a period of two weeks. In the first phase, the 52 users completed an online questionnaire that measured the specific amounts of advertising clips they were willing to watch in exchange for points and credits to unlock contacts. The questionnaire asked users about which different actions they felt would acceptable to unlock their selected profiles. For example, it asked whether the user would agree to follow the instruction of a clip and perform a survey in referring website to obtain points; or it asked whether the user would agree to act as social tie for a friend and to endorse them for a date by performing a puzzle challenge. This phase was designed to understand the mindset and mental acceptance of users towards behaving in a particular way (according to the wishes of the service provider) to receive value.

The second phase was an experiment conducted in the Danish App Lab at Aalborg University of Copenhagen, Denmark. For this phase, a copy of a platform that was originally developed for social dating was purchased, and two volunteer developers customized it according to the requirements of the experiment. For example, to personalize the platform for this research, a points-foraction system was added to enable the awarding of points to users for completing actions such as watching advertising clips, which could then be "spent" to unlock and view the profiles of other users (potential partners).

Fourteen users were asked to use the prototype platform and search for interesting matches. When they found interesting profiles, they were encouraged to try to contact them. The mechanism of the platform was to provide two options for contacting the owners of profiles: by paying a monthly fee (the typical model for most dating websites) or by earning and spending points. The points could be earned by watching advertising clips; for example, by watching the full 30 seconds of an advertising clip, a user would receive 30 points. Points could then be spent, for example, to send a message to a contact, which would cost 20 points. Also, actions that boost the user profile cost more, such as requesting recommendations and endorsements from social connections, or requesting matchmaking from common friends. By this choice of mechanism, users have the option to spend money or sell their time and attention to earn the same value.

Data was collected through a back-end managerial panel that recorded user interactions, such as what criteria they have searched, which profiles they have viewed, what advertising clips they have watched and for how long they watched them, how they have spent credits, and so on. At the end of the second phase, this information was retrieved from managerial panel and analyzed. Interpretation of findings was done by comparing what the users previously expressed in the questionnaire to their subsequent actions when using the prototype. The data included information about their actions as well as the time, energy, and attention they spent to receive value.

\section{Findings and Analysis}

The survey conducted in the first phase of the research shows most of users did not wish to be treated as commodity when the strategy has been expressed explicitly in those terms. But, when they were offered opportunities to do something to receive a specific value, they considered it and expressed that they may do it. When they were asked, "Would you agree to sell your attention by watching a clip and answering related questions in exchange for an amount of money that exceeds your usual hourly working income?", 92\% of respondents answered "yes" or "possibly yes".

The prototype tested in the second phase of the research provides insight for developing more sustainable business models. The analysis of users' actions shows that they are willing to trade their attention for the value and consider it as a trade-off (Box 1). If the value is not perceived as sufficient, users will not sell their attention. Users who did not find their match or an interesting profile did stop the test and did not continue thereafter. But, those who found an interesting profile were encouraged to behave in such a way as to obtain the value. In addition, they expended efforts to unlock "extras" to improve their profiles and to receive social approval, which increased their chance of acceptance by the respective user.

The findings of the experiment, derived from an analysis of the information extracted from the managerial panel, show that the business models designed by a focus on a trade-off of value and attention may be con- 


\section{Audience Commodification: A Source of Innovation in Business Models}

\section{Datis Khajeheian}

Box 1. Main actions performed by test users on the prototype dating platform

Action: Test users searched voluntarily for advertising clips, then they watched the clips and answered the embedded questions to receive points.

In traditional advertising, users ignore clips easily or grudgingly tolerate theme. On the prototype platform, they receive points by voluntarily watching clips. This model changes their impression of the clips and influences their behaviour. The benefit for a service provider is higher revenues from advertisers who value the users' higher level of engagement with their messages.

Action: Test users performed deliberate actions and watched more advertising to unlock more features for improving their profiles and to increase their own "value" on the platform.

In traditional dating platforms, users complete their profile and wait for contact by another user who finds them interesting. Here, users have the possibility to increase their "value" and to be seen by more potential partners. Again, selling attention leads to success in the market.

Action: Test users acted as human engines of matchmaking by introducing users they know to possible partners; this approach works better than algorithms that find matches based on user questionnaires.

In traditional subscription models, payment provides possibly unlimited contacts. The result is a lower rate of response, because many users cannot be sure that they are not part of bulk messages from premium accounts. Here, unlocking every profile costs points. This "cost" prevents bulk messages and requires users to sell their attention to receive points and then spend the points to unlock a limited number of profiles. Thus, users select profiles to contact based on their perceived "value".

sidered as more sustainable models for companies with advertising-based revenue models. Current models such as "freemium", "free for advertising", and "embedded advertising" can be promoted by a change in focus of value delivery. Users should be presented with a clear value proposition for doing something that will benefit the deliverer of that value. Watching an advertising clip fully and responding to the message is one way for service provider to generate income and to return the value. It is a business model based on mutual benefit and straightforward value provision.

\section{Conclusions}

In business model generation, "value" and "customer" are considered as two central blocks. The base of any business model is to deliver value to the customer and to generate revenue. Also in many businesses, especially those in the media industry, a business model is multi-sided and has to serve two different groups of customers: advertisers and audiences. Large audiences encourage advertisers to spend more. Thus, in multisided business models, direct revenue is generated from advertisers, but it depends on audience size. In- novation in business models can be based on finding new and more efficient ways of communication between customers and advertisers.

Using these results, the theory of audience commodification and Google's best practice can provide insight for developing a dynamic business model for the businesses that use multi-sided approaches. The prototype online dating platform tested in this study received strong positive feedback from test users in comparison with the typical free or subscription-based models in the marketplace today. Most users expressed willingness to use a product with such a business model and to "sell" their attention and action in exchange for value in the form of unlocking and contacting a selected profile.

One contribution of this research is to suggest self-commodification as a type of audience commodification. Although in the political economy of communication, industry and the media are blamed for the commodification of customers, here customers offer themselves as a commodity to receive value from businesses that sell higher-value advertising opportunities. The next step of 


\section{Audience Commodification: A Source of Innovation in Business Models}

\section{Datis Khajeheian}

the research would be based on details of value that customers agree to create for service providers, such as response to advertising clips and the possibility of purchasing or sharing the advertising to their network of friend.

The results show that the business model that is based on audience commodification may be an alternative for current advertising-based models in many social media services. Further, the results may lead companies to deliver value as a customer's partner instead of seller. From the perspective of innovation, this proposed business model is an incremental innovation in business model generation. It is not an addition or removal or change in the logic of business models, but it is a change in value system innovation by a clear trade-off of requested action and value delivery (Table 1).

Time is the critical resource in our era. The competition is focused on holding the attention of users. Some platforms such as Facebook and Instagram are closed ecosystems that are designed to keep user inbound (Derakhshan, 2015). A dynamic business model should be "time based" to exploit the power of the time that users spend for the service and to increase the time they spend inside the platform. The provision of perceived value creates an exchange between user and media, which increases the access of media to advertisers based on multi-sided business model. Also, advertisers seek maximum efficiency from their advertising

Table 1. Types of value received by the beneficiaries

\begin{tabular}{lll}
\hline Beneficiary & Types of Value Received \\
\hline Customers & - $\begin{array}{l}\text { Unlocking of premium value } \\
\text { Ability to pay with an abundant } \\
\text { resource (attention) instead of a } \\
\text { scarce resource (money) } \\
\text { - }\end{array}$ \\
& $\begin{array}{l}\text { Opportunity to sell something of } \\
\text { value: attention and value }\end{array}$ \\
\hline Advertisers & Engaged customer attention \\
\hline Service Providers & Audience interaction \\
\hline & $\begin{array}{l}\text { Opportunity to provide users with } \\
\text { value (without paying them) } \\
\text { Creation of a high-demand } \\
\text { offering to advertisers } \\
\text { Development of a customer } \\
\text { engagement program }\end{array}$ \\
\hline
\end{tabular}

budgets. The number of page visits, the number of attendees at promotional events, and the volume of sales, are examples of the measures used to assess budget efficiency (Sissors \& Baron, 2010). In this research, the dynamic business model maximizes engagement in an advertiser's messages by target customers, therefore it benefits advertisers. From the other side, this business model enables customers to sell their time in exchange for perceived value. Such business models improve interactions with media by advertisers and customers, and also advance the current business models towards more value-driven and user-centric mechanisms of revenue generation.

These conclusions are based on interpretation of findings from a questionnaire and a small sample of users testing a prototype online dating platform. The number and characteristics of respondents, the period of time, the questions in the questionnaire, and possible actions available in the platform, the pervasiveness of research, and also the level of completeness of the business model are limited and this limitation affects the generalization of findings. However, this research is an effort to test the possibility of creation a new business model based on a direct trade of value from business by attention and action from users. The approach will be tested further in subsequent phases of the research project, and hopefully it will also encourage others to study the value of audience commodification as a source of innovative business models.

\section{Acknowledgments}

This project was facilitated by the equipment and facilities of the Danish App Lab in Aalborg University in Copenhagen, Denmark. The author also acknowledges the Center for Communication, Media and Information Technologies (CMI) for their support in developing both the theory and practice used in this research. Moreover, the author acknowledges Ellwand Co. for its cooperation in conducting this experiment. 


\section{Audience Commodification: A Source of Innovation in Business Models}

\section{Datis Khajeheian}

\section{About the Author}

Datis Khajeheian is a lecturer in the Center for Communication, Media and Information Technologies in Aalborg University of Denmark. He earned his PhD in Media Management and his MA in Entrepreneurship with a specialty in New Venture Creation. Datis is Head of the special interest group of "Emerging Media Markets" in the European Media Management Association. His mission is to lead academic and practical research to understand the emergence of new markets and opportunities in niche areas for international media companies.

\section{References}

Arvidsson, A., \& Bonini, T. 2015. Valuing Audience Passions: From Smythe to Tarde. European Journal of Cultural Studies, 18(2): 158-173. http://dx.doi.org/10.1177/1367549414563297

Sissors, J. Z., \& Baron, R. B. J. 2010. Advertising Media Planning. New York: McGraw Hill Professional.

Chesbrough, H. 2007. Business Model Innovation: It's Not Just about Technology Anymore. Strategy \& Leadership, 35(6): 12-17. http://dx.doi.org/10.1108/10878570710833714

Chesbrough, H. 2010. Business Model Innovation: Opportunities and Barriers. Long Range Planning, 43(2): 354-363. http://dx.doi.org/10.1016/j.lrp.2009.07.010

Chesbrough, H., \& Rosenbloom, R. S. 2002. The Role of the Business Model in Capturing Value from Innovation: Evidence from Xerox Corporation's Technology Spin-off Companies. Industrial and Corporate Change, 11(3): 529-555.

http://dx.doi.org/10.1093/icc/11.3.529

Darr, D., \& Pretzsch, J. 2008. Mechanisms of Innovation Diffusion under Information Abundance and Information Scarcity-On the Contribution of Social Networks in Group vs. Individual Extension Approaches in Semi-Arid Kenya. Journal of Agricultural Education and Extension, 14(3): 231-248. http://dx.doi.org/10.1080/13892240802207676

De Mare, G., Granata, M. F., \& Nesticò, A. 2015. Weak and Strong Compensation for the Prioritization of Public Investments: Multidimensional Analysis for Pools. Sustainability, 7(12): 16022-16038.

http://dx.doi.org/10.3390/su71215798

Derakhshan H. 2015. The Web We Have to Save. Medium, July 14, 2015. Accessed June 4, 2016:

https://medium.com/matter/the-web-we-have-to-save2eb1fe15a426

DiZerega, G. 2004. Toward a Hayekian Theory of Commodification and Systemic Contradiction: Citizens, Consumers and the Media. The Review of Politics, 66(3): 445-468.

http://dx.doi.org/10.1017/S0034670500038869
Dubosson-Torbay, M., Osterwalder, A., \& Pigneur, Y. 2002. E-Business Model Design, Classification, and Measurements. Thunderbird International Business Review, 44(1): 5-23.

http://dx.doi.org/10.1002/tie.1036

Ekdahl, A., \& Sandell, J. 2014. Customer Involvement in Business Model Innovation: A Case Study in the Medical Instrument Industry. Master's Thesis. Umeå, Sweden: Umeå School of Business and Economics.

Falkinger, J. 2008. Limited Attention as a Scarce Resource in Information-Rich Economies. The Economic Journal, 118(532): 1596-1620.

http://dx.doi.org/10.1111/j.1468-0297.2008.02182.x

Fleissner, P. 2006. Commodification, Information, Value and Profit. Poiesis \& Praxis, 4(1): 39-53.

http://dx.doi.org/10.1007/s10202-005-0007-y

Fuchs, C. 2012. Dallas Smythe Today - The Audience Commodity, the Digital Labour Debate, Marxist Political Economy and Critical Theory. Prolegomena to a Digital Labour Theory of Value. tripleC: Communication, Capitalism \& Critique, 10(2): 692-740.

Hawrysz, L., \& Foltys, J. 2015. Environmental Aspects of Social Responsibility of Public Sector Organizations. Sustainability, 8(1): 19.

http://dx.doi.org/10.3390/su8010019

Hearn, A. 2008. Meat, Mask, Burden: Probing the Contours of the Branded Self. Journal of Consumer Culture, 8(2): 197-217. http://dx.doi.org/10.1177/1469540508090086

Hedman, J., \& Kalling, T. 2003. The Business Model Concept: Theoretical Underpinnings and Empirical Illustrations. European Journal of Information Systems, 12(1): 49-59. http://dx.doi.org/10.1057/palgrave.ejis.3000446

James, R. 2012. Out of the Box - Freescale: How Free Models Scale in the World of Information. Business Information Review, 29(2): 95-98.

http://dx.doi.org/10.1177/0266382112450238

Jennes, I., Pierson, J., \& Van den Broeck, W. 2014. User Empowerment and Audience Commodification in a Commercial Television Context. The Journal of Media Innovations, 1(1): 70-85. http://dx.doi.org/10.5617/jmi.vli1.723

Johnson, M. W., Christensen, C. M., \& Kagermann, H. 2008. Reinventing Your Business Model. Harvard Business Review, 86(12): 57-68.

Kang, H., \& McAllister, M. P. 2011. Selling You and Your Clicks: Examining the Audience Commodification of Google. tripleC: Communication, Capitalism \& Critique, 9(2): 141-153.

Magretta, J. 2002. Why Business Models Matter. Harvard Business Review, 80(5): 86-92.

Manzerolle, V. 2010. Mobilizing the Audience Commodity: Digital Labour in a Wireless World. Ephemera: Theory \& Politics in Organization, 10(3/4): 455-469.

Masiello, B., \& Whitten, A. 2010. Engineering Privacy in an Age of Information Abundance. Paper presented at the AAAI Spring Symposium: Intelligent Information Privacy Management, March 22-24, 2010, Palo Alto, CA. 


\section{Audience Commodification: A Source of Innovation in Business Models}

\section{Datis Khajeheian}

Morris, M., Schindehutte, M., \& Allen, J. 2005. The Entrepreneur's Business Model: Toward a Unified Perspective. Journal of Business Research, 58(6): 726-735.

http://dx.doi.org/10.1016/j.jbusres.2003.11.001

Murdock, G. 2011. Political Economies as Moral Economies: Commodities, Gifts, and Public Goods. In J. Wasko, G. Murdock, \& H. Sousa (Eds.), The Handbook of Political Economy of Communications: 11-40. Oxford, UK: Wiley-Blackwell. http://dx.doi.org/10.1002/9781444395402.ch1

Osterwalder, A. 2004. The Business Model Ontology: A Proposition in a Design Science Approach. Doctoral dissertation. Lausanne, Switzerland: University of Lausanne

Osterwalder, A., \& Pigneur, Y. 2010. Business Model Generation: A Handbook for Visionaries, Game Changers, and Challengers. Hoboken, NJ: Wiley.

Prodnik, J. 2012. A Note on the Ongoing Processes of Commodification: From the Audience Commodity to the Social Factory. tripleC: Communication, Capitalism \& Critique, 10(2): 274-301.

Radomska, J. 2015. The Concept of Sustainable Strategy Implementation. Sustainability, 7(12): 15847-15856. http://dx.doi.org/10.3390/su71215790

Rappa, M. A. 2004. The Utility Business Model and the Future of Computing Services. IBM Systems Journal, 43(1): 32-42. http://dx.doi.org/10.1147/sj.431.0032

Smythe, D. W. 1977. Communications: Blindspot of Western Marxism. CTheory, 1(3): 1-27.
Smythe, D. W. 1981. On the Audience Commodity and Its Work. In M. G. Durham \& D. M. Kellner (Eds.), Media and Cultural Studies: Keyworks: 230-256. Oxford, UK: Wiley-Blackwell

Stewart, D. W. \& Zhao, Q. 2000. Internet Marketing, Business Models, and Public Policy. Journal of Public Policy \& Marketing, 19(2): 287-296.

http://dx.doi.org/10.1509/jppm.19.2.287.17125

Suddaby, R., \& Greenwood, R. 2001. Colonizing Knowledge: Commodification as a Dynamic of Jurisdictional Expansion in Professional Service Firms. Human Relations, 54(7): 933-953. http://dx.doi.org/10.1177/0018726701547007

Thorén, C. 2011. The Political Economy of News Value and the Commodification of the General Intellect. Paper presented at the Nordic Academy of Management (NFF) 2011 Conference, August 20-24, 2011, Stockholm, Sweden: Stockholm University.

Week, B. 2000. Knowledge Management and New Organization Forms: A Framework for Business Model Innovation. In Y. Malhotra (Ed.), Knowledge Management and Virtual Organizations: 2-19. Hershey, PA: Idea Group Publishing.

Zott, C., \& Amit, R. 2008. The Fit between Product Market Strategy and Business Model: Implications for Firm Performance. Strategic Management Journal, 29(1): 1-26. http://dx.doi.org/10.1002/smj.642

Zott, C., Amit, R., \& Massa, L. 2011. The Business Model: Recent Developments and Future Research. Journal of Management, 37(4): 1019-1042.

http://dx.doi.org/10.1177/0149206311406265

Citation: Khajeheian, D. 2016. Audience Commodification: A Source of Innovation in Business Models. Technology Innovation Management Review, 6(8): 40-47. http://timreview.ca/article/1010

Keywords: business model, technology entrepreneurship, audience commodification, value marketing, innovation 